\title{
Stjórnkerfismiðjur: Samhent stjórnsýsla í framkvæmd á Íslandi
}

\author{
Pétur Berg Matthíasson, stjórnmála- og stjórnsýslufræđingur í forsætis- \\ ráđuneytinu
}

\section{Útdráttur}

Stjórnkerfismiðjur eru jafnan einingar innan forsætisráðuneyta sem hafa pað hlutverk að veita forsætisráðherra stuðning við að ná fram pólitískri og tæknilegri samhæfingu á aðgerðum stjórnvalda, við stefnumótun og við eftirfylgni mála. Jafnframt að upplýsa um ákvarðanir og frammistöðu stjórnvalda. Rannsóknir á stjórnkerfismiðjum gefa til kynna að ríki setji slíkar einingar á fót. Annars vegar til að mæta nútíma áskorunum innan stjórnkerfisins á tímum alpjóðavæðingar. Hins vegar til að draga úr óhóflegri valddreifingu sem varð að veruleika með innleiðingu nýskipunar í ríkisrekstri í mörgum ríkjum. Í fyrsta hluta greinarinnar er fjallað um hlutverk, verkefni og skipulag stjórnkerfismiðja. Í öðrum hluta er greint frá starfsemi stjórnkerfismiðja á Norðurlöndunum og pær bornar saman við sambærilega einingu á Íslandi. Gerð er tilraun til að greina próun stjórnkerfismiðja, frá nýskipan að samhentri stjórnsýslu. Auk pess er fjallað um pær kenningar sem settar hafa verið fram af fræðimönnum til að skýra mismunandi leiðir ríkja til að styrkja stjórnkerfismiðjur. Að lokum er fjallað um próun stjórnkerfismiðju á Íslandi með hliðsjón af peim kenningum sem settar hafa verið fram, s.s. um fjölgun ráðgjafa, skipulagða samhæfingu og markvisst eftirlit. Í síðasta kaflanum er jafnframt stuðst við nýlega könnun frá árinu 2018 sem gerð var sérstaklega fyrir pessa rannsókn. Könnunin er endurtekning á sambærilegri könnun OECD frá árinu 2003.

Efnisorð: Stjórnkerfismiðja; forsætisráðuneyti; stefnumótun; samhæfing; eftirfylgni. 


\title{
Centre of Government: Implementing joined up govern- ment in Iceland
}

\begin{abstract}
Centre of Government refers to the institution or group of institutions that provide direct support to the country's chief executive, generally for the political and technical coordination of government actions, strategic planning, performance monitoring, and communication of the government's decisions and achievements. Recent studies of centres of government literature suggest that states are empowering units like that to ensure stronger central coordination when facing crosscutting and wicked policy issues. In addition to that, previous waves of government reforms have decentralized decision-making and implementation authority to autonomous or quasi-autonomous agencies forcing states to regain control and increase coordination. The first part of this article discusses the role, tasks and the organisational setup of centres of governments and compares the unit in Iceland to the Nordic countries. The second part focuses on the transformation from New Public Management (NPM) to Joint up Government as well as examining theories on the enhancement of centres of government. The last part follows the transformation of the centre of government in Iceland, examining the circumstances and explaining the development within the Office of the Prime Ministers since 2003. The analysis indicates that the centre of government in Iceland has come a long way in recent years and is following the models of countries that implemented new public management during the 80 s and 90 s.
\end{abstract}

Keywords: Centre of government; New public management; joined Up Government; coordination; monitoring.

\section{Inngangur}

Stjórnkerfismiðja er vélin í bílnum par sem hennar hlutverk er að styðja við pólitíska ráðamenn og tryggja að verkefni stjórnvalda nái fram að ganga (Haddad, Klouche \& Heneine 2010; Institute for Government 2013). Stjórnkerfismiðja er hugtak sem lítt hefur verið notað innan stjórnsýslufræða á Íslandi en sumir kannast eflaust við enska hugtakið „Centre of Government“. Alpjóðastofnanir á borð Efnahags- og framfarastofnunina (OECD), Evrópusambandið, Ameríski próunarbankinn (IADB), Alpjóðabankinn og fleiri hafa sýnt starfsemi stjórnkerfismiðja mikinn áhuga og gefið út fjölda rita og jafnvel haldið úti vinnuhópum á pessu sviði. Helstu kenningarnar sem uppi eru um próun stjórnkerfismiðja og sí aukið hlutverk peirra á síðustu árum má annars vegar rekja til peirra áskorana sem stjórnvöld standa nú frammi fyrir sem ganga pvert á hefðbundið skipulag ráðuneyta. Hins vegar til peirra umbóta sem innleitt voru síðastliðna áratugi og fólust m.a. í aukinni valddreifingu til stofnana og dreifðari ákvörðunartöku í anda nýskipunar í ríkisrekstri (e. New Public Management, NPM). Í báðum tilvikum er reynt að hverfa frá sílóahugsun en hún getur nefnilega dregið úr samhæfingu og sampættingu 
og par með úr áhrifum og árangri innan stjórnsýslunnar. Verið er að leggja meiri áherslu á heildarsýn, samhæfingu og samstarf með notkun aðferða úr öðrum fræðigreinum (Christensen \& Lægreid 2007).

рó nokkuð hefur verið fjallað um samhenta stjórnsýslu, á ensku ýmist ,joined-up government“ еða „whole-of-government“. Hins vegur hefur jafnan gleymst að fjalla um framkvæmdina í skrifum fræðimanna um samhenta stjórnsýslu en par kemur stjórnkerfismiðjan til sögunnar. Stjórnkerfismiðja er jafnan eining innan forsætisráðuneyta sem hefur skýrt hlutverk til að samhæfa og fylgja eftir málum ríkisstjórna. Einnig eru dæmi um verkefni sem skilgreind hafa verið sem hluti af stjórnkerfismiðju. Pau kunna að hafa verið leyst af hendi í öðrum ráðuneytum, s.s. fjármálaráðuneytum og utanríkisráðuneytum. Pó reynt sé að skýra í pessari grein hvernig stjórnkerfismiðja hefur verið að próast hér á landi eru einnig tekin dæmi af sambærilegri próun í öðrum ríkjum. Ætlunin er að fjalla um viðfangsefni innan stjórnsýslufræðinnar sem kalla má stjórnkerfismiðjur (e. Centre of government). Раð er ekki um auðugan garð að gresja pegar kemur að rannsóknum um petta efni. Nokkuð er pó til af skýrslum og fræðilegum samantektum unnum af fyrrnefndum alpjóðastofnunum. Viðfangsefnið hefur ekki verið rannsakað hér á landi en pó má finna umfjöllum um samhenta stjórnsýslu í skýrslu forsætisráðuneytis frá árinu 2010 um hlutverk forsætisráðuneytis í anda stjórnkerfismiðja.

Í pessari rannsókn er stuðst við ýmsar erlendar rannsóknir sem gerðar hafa verið á síðastliðnum árum á stjórnkerfismiðjum. Đau gögn sem unnið er með í pessari grein koma annars vegar úr könnunum á vegum OECD sem framkvæmdar voru árið 2003 og 2017. Um er að ræða ólíkar rannsóknir og hefur efnið úr báðum rannsóknunum ekki birst í fræðitímaritum áður. Gögnin úr 2017 könnuninni eru notuð til að bera saman hlutverk stjórnkerfismiðja á Norðurlöndunum við stöðuna á Íslandi. Könnunin frá 2003 er án efa með peim fyrstu sem gerð var sérstaklega um verkefni og hlutverk stjórnkerfismiðja í Evrópu. Par sem Ísland tók peirri könnun á sínum tíma eru til dýrmætar upplýsingar um stöðuna hér á landi við upphaf 21. aldar. Höfundur ákvað að endurtaka könnunina til að geta greint hver próunin hefur verið hér á landi sl. 15 ár. Forsætisráðuneytið svaraði könnuninni í maí 2018 og er heill kafli lagður undir greiningu á próun stjórnkerfismiðju hér á landi í lok greinarinnar.

Í pessari rannsókn er í fyrsta lagi fjallað um hlutverk og tilgang stjórnkerfismiðja, peirra meginverkefni og verklag. Баð felur m.a. í sér lýsingu á vinnulagi starfsmanna stjórnkerfismiðja. Hér er m.a. reynt að svara pví af hverju ríki ákveða að styrkja miðjuna. Eins er ætlunin að ræða um hvernig afleiðingar af nýskipan í ríkisrekstri hafi leitt til pess að ríki hafi hin síðari ár ákveðið að styrkja aftur miðlægt hlutverk stjórnkerfisins. Fjallað er um pær aðferðir sem helstu nágrannaríkin hafa notast við til að styrkja miðjuna. Má par m.a. nefna bætta samhæfingu, aukna eftirfylgni og fjölgun aðstoðarmanna. Fram kemur að ríki velja ekki aðeins ólíkar leiðir heldur getur útfærsla tiltekinnar aðferðar verið mjög mismunandi. Megintilgangur greinarinnar er aftur á móti að svara pví hvernig til hefur tekist að efla forsætisráðuneytið á Íslandi sem stjórnkerfismiðju síðastliðinn 20 ár. Hefur Ísland verið að færast nær nágrannaríkjunum hvað pessi mál varðar og hvaða tæki hefur verið stuðst við? 


\section{Hvað eru stjórnkerfismiðjur?}

Hugtakið stjórnkerfismiðja (e. Centre of government) vísar til stofnunar eða hóps stofnana sem veita forsætisráðherra stuðning við að ná fram pólitískri og tæknilegri samhæfingu. Á pað við um aðgerðir stjórnvalda, við stefnumótun og við eftirfylgni mála, og við að upplýsa um ákvarðanir og frammistöðu stjórnvalda (Alessandro o.fl. 2013). Miðlæg stjórnkerfismiðja er ekki nýtt fyrirbæri pó hugtakið hafi verið lítt notað hér á landi. Rekja má forvera skrifstofu ríkisstjórnarinnar (e. Cabinet Office) í Bretlandi allt aftur til ársins 1916 pegar henni var formlega falið að samhæfa stefnur og áætlanir stjórnvalda vegna aukins álags á stjórnsýsluna í fyrri heimsstyrjöldinni. Í Bandaríkjunum var Endurskipulagslöggjöfin (e. Reorganization Act) sampykkt árið 1939, var pá búin til sérstök forsetaskrifstofa (e. The Executive Office of the President) eftir að Brownlow nefndin hafði lýst pví yfir að forsetinn pyrfti frekari aðstoð (Relyea 2008).

Hugtakið stjórnkerfismiðja, eins og svo mörg önnur hugtök innan stjórnsýslufræðanna, er nokkuð á reiki og getur haft mismunandi skilgreiningar eftir pví hvers konar stjórnkerfi um er að ræða. Samkvæmt nýlegri rannsókn OECD telja um 78\% aðildarríkja að stjórnkerfismiðja sé stjórnsýslueining sem pjóni framkvamdavaldinu, p.e.a.s. forseta eða forsatisrádherra, auk rikisstjórnarinnar i heild (OECD 2018). Stjórnkerfismiðja er hvorki nákvæmt lagalegt eða tæknilegt hugtak en í almennu tali er átt við stofnun eða stofnanir á æðsta stigi stjórnsýslunnar sem vinna að stefnu stjórnvalda, stefnumótun og fjárlögum. Vanalega eru petta skrifstofur sem heyra undir forsætisráðherra eða forseta, ríkisstjórnir eða ráðherranefndir, fjármálaráđuneyti, háttsettir diplómatar eða sérstakar hugveitur. (Ministry of Finance Finland 2013; James \& Ben-Gera 2004; World Bank 2010).

Innan fræðanna er deilt um hvort fjármálaráðuneyti teljist til stjórnkerfismiðja. Pó að fjármálaráđuneyti teljist jafnan til fagráðuneyta (e. line ministries) falla pau að hluta til innan peirra skilgreininga sem notaðar eru um stjórnkerfismiðjur. Hlutverk peirra er par frekar samhæfing en pað að veita pjónustu. Pau gegna pví sambærilegu hlutverki og skrifstofur stjórnkerfismiðja í forsætisráðuneytum. Sérstaklega er hér átt við hlutverk peirra við gerð fjárlaga sem felur í sér samhæfingu pvert á öll ráouneytin, auk pess sem pau gegna mikilvægu hlutverki við stefnumótun (Alessandro o.fl. 2013).

Í sumum ríkjum eru verkefni pessarar miðlægu einingar eins og hún er skilgreind af OECD, framkvæmd af tveimur eða fleirum aðilum innan kerfisins, eins og t.d. forsætisráðuneyti og fjármálaráđuneyti. Í einhverjum tilvikum kann petta að vera enn flóknara par sem um er að ræða bæði forsætisráðherra og forseta með pólitískt vald (OECD 2018). Tilraunir hafa verið gerðar til að greina hlutverk stjórnkerfismiðja eftir ólíkri stjórnskipan, p.e. forsetaræðis, forsetapingræðis og pingræðisfyrirkomulaginu. Í stjórnskipun forsetaræðis er forseti æðsti valdhafi sem leiðir stjórnkerfið (Sartori 1994). Við pessa skipan er pað ríkisstjórnarinnar að pjóna forsetanum, sem skipar ráðherra og rekur. Hann ber ábyrgð á ákvörðunum og pví er pað hlutverk stjórnkerfismiðju að pjóna honum. Par sem stjórnskipan grundvallast á forsetapingræði deilir forseti ríkisforystu með forsætisráðherra. Par kann að gilda sú meginregla að ráðherrar beri sameiginlega ráðherraábyrgð (e. collective ministerial responsibility) en við slíkar aðstæður er pað ekki einvörðungu hlutverk stjórnkerfismiðjunnar að pjóna forsætisráðherra heldur stærri 
heild (Alessandro o.fl. 2013). Við stjórnskipan sem grundvallast af pingræði er hlutverk forseta ópólitískt. Stjórnkerfismiðjan er pví fyrst og fremst að pjónusta forsætisráðherra og ríkisstjórn hans. Rannsóknir á stjórnkerfismiðjum gefa til kynna að pað sé ekkert eitt líkan framar öðru sem hentar betur fyrir ríki. Hvert ríki hefur sína nálgun sem próast hefur í gegnum áratugina, par sem pættir eins og löggjafarmenning, áherslur ráðamanna, starfsmanna og fleira hefur mótað eininguna og mun gera um ókomna framtíð (Alessandro o.fl. 2013; European Commission 2017).

\subsection{Hlutverk stjórnkerfismiðja innan stjórnkerfisins}

Prátt fyrir að rannsóknir gefi ekki til kynna að eitthvert eitt fyrirmyndarlíkan sé til staðar, má greina fjölda verkefna sem flestar stjórnkerfismiðjur sinna, p.e. stuðningur við oddvita ríkisstjórnar, áætlanagerð, samhæfing stefnumála, vöktun frammistöðu, ráðgjöf um stefnumál, ráðgjöf um frumvarpagerð, umsýsla með innri vef ráðuneyta og veiting fjármuna til verkefna (European Commission 2017). Helstu verkefnin teljast jafnan vera pólitísk samhæfing, stefnumótandi áætlunargerð, samhæfing stefna og áætlana, vöktun/ eftirfylgni með frammistöðu og upplýsingagjöf um aðgerðir og árangur.

\section{Pólitisk sambafing}

Forsætisráðherrar purfa að hafa skýra sýn á hvert sé markmið peirra og stefna pegar peir semja við ping, stjórnmálaflokka, félagasamtök og hagsmunahópa um að koma stefnum sínum í framkvæmd. Enginn einn einstaklingur getur petta án stuðnings. Forsætisráðherra parf upplýsingar frá ólíkum aðilum svo að hægt sé að vega og meta rökin í málunum og komast að niðurstöðu. Til viðbótar parf hann að leiða ríkisstjórnina og stjórnkerfið til að tryggja samræmda stefnu (Bonvecchi \& Scartascini 2011). Stjórnkerfismiðjur eru tæki sem forsætisráðherrar geta notað til að ná fram markmiðum sínum. Að leiða stjórnkerfið felur í sér að eiga í samskiptum við einkageirann og frjáls félagasamtök. Að bregðast við, stjórna og leysa átök sem kunna að koma upp, s.s. verkföll, mótmæli og fleira fellur jafnan undir hlutverk stjórnkerfismiðja (Egaña \& Chateau 2011).

\section{Stefnumótandi ácetlanagerঠ}

Samstarfsyfirlýsingar stjórnvalda geta verið mjög mismunandi en pað sem pær eiga jafnan sameiginlegt er að pær eru sjaldan mjög ítarlegar. Til að aðgerðavæða samstarfsyfirlýsingar purfa forsætisráðherrar að treysta á teymi innan stjórnkerfismiðjunnar til að vinna með öðrum ráðuneytum og stofnunum við að skilgreina nánar forgangsmál, markmið og mælikvarða. Stjórnkerfismiðjur eru gagnlegar til að halda utan um markmið stofnana og aðlaga pau að forgangsmálum ríkisstjórna (OECD 2007). Stjórnkerfismiðjur purfa að tryggja að í fjárlögunum endurspeglist verkáætlun stjórnvalda (Evans 2013). Skýr tenging milli forgangsmála og fjárveitinga er nauðsynleg til að styðja við sýn stjórnvalda og pau verkefni sem ráðuneyti og stofnanir purfa að ráðast í. Fjölmargar rannsóknir á stjórnkerfismiðjum færa rök fyrir pví að einingin ætti einvörðungu að einbeita sér að fáum forgangsmálum (Barber 2008; Prats i Catalá \& Villoria 2011; Egaña \& Chateau 2011). Sumir telja að stjórnkerfismiðjur ættu eingöngu að starfa með peim ráðuneytum par sem 
getan til að takast á við verkefnin er takmörkuð og meiri pörf er á aðstoð (Chakabrarti 2007).

\section{Sambafing stefna og áctlana}

Opinber stjórnsýsla hefur jafnan verið skipulögð með lóðréttum hagnýtum línum, sem gerir ráð fyrir skýrri verkaskiptingu og sérhæfingu en við slíkar aðstæður er hætta á meiri sundrungu og skorti á samhæfni ríkisstjórnarinnar í heild sinni. Stjórnkerfismiðjum er jafnan ætlað að samræma aðgerðir stjórnvalda en skortur á skilvirkri samhæfingu getur leitt til pess að verkefni séu færð á milli stofnana. Afleiðingin af slíku kann að vera að verkefni verði ekki leyst, tvíverknaður á sér stað sem veldur ruglingi, sóun og átökum á milli aðila innan kerfisins o.s.frv. (Gaetani 2011).

\section{Vöktun/ eftirfylgni med frammistödu}

Með pví að forgangsraða og samræma gerð stefna og áætlana er forsætisráðherra að leitast við að móta skýra sýn fyrir stjórnsýsluna. Til að tryggja að svo verði parf stjórnkerfismiðja jafnframt að vakta forgangsmálin, svo að forsætisráðherra hafi yfirsýn yfir framgang mála. Um er að ræða nokkuð umfangsmikið verkefni eftir pví hversu ítarlegt matið parf að vera. Engu að síður geta forsætisráðherrar með slíkar upplýsingar brugðist við pegar frammistaðan er óásættanleg. Hins vegar ætti vöktun verkefna að hafa hvetjandi áhrif á ráðherra til að bæta árangur áður en forsætisráðherra parf að skipta sér af.

Dæmi er um stjórnkerfismiðjur sem voru sérstaklega settar á laggirnar til að fylgja eftir forgangsmálum stjórnvalda, má hér nefna Bretland, Ástralíu og Chile. (Lindquist 2007; Barber 2008; Richards \& Smith 2006; Wanna 2006; Dumas, Lafuente \& Parrado 2013). Dessar einingar hafa tvípætt hlutverk, annars vegar ex-ante vöktun á nýjum stefnum, með pví að spyrja spurninga um t.a.m. hvernig stefna verður innleidd o.s.frv. Hins vegar að fylgjast með framgangi stefna og veita aðstoð pegar pess gerist pörf. Stjórnkerfismiðja stýrir yfirleitt ekki eftirlitinu, heldur samræmir pað og tryggir að viðeigandi ráðuneyti og stofnanir séu að vakta framgang og upplýsa um stöðu mála.

OECD hefur útfært ítarlegan lista yfir hlutverk og verkefni stjórnkerfismiðja. Í töflu 1 má finna svör stjórnkerfismiðja á Norðurlöndum við spurningarkönnun OECD frá árinu 2017 (OECD 2018). Svörin koma frá ríkjunum sjálfum og er pví um sjálfsmat að ræðа. Раð sem taflan greinir hins vegar ekki frá er hversu vel pessum stjórnkerfismiðjum gengur að sinna pessum verkefnum. Niðurstöður gefa til kynna að hlutverk flestra miðlægra eininga á Norðurlöndunum er nokkuð svipað. Í umræðum um stjórnkerfismiðju á Íslandi hefur verið litið til Norðurlandanna, pá sér í lagi til Dana og Finna. Í sumum tilfellum eru framkvæmdaraðilar fleiri en ábyrgð kann oftar en ekki að liggja hjá einu ráðuneyti. Á Íslandi eru sum verkefnin mjög skýr og nefnd í forsetaúrskurði, stjórnarráðslögum eða á vefsíðu ráðuneyta, par sem finna má ítarlega uppröðun á verkefnum ráðuneyta. 
Pétur Berg Matthíasson

Tafla 1. Meginhlutverk og ábyrgð stjórnkerfismiðja á Norðurlöndunum (OECD 2018)

\begin{tabular}{|c|c|c|c|c|c|}
\hline Hlutverk stjórnkerfismiðja & Danmörk & Finnland & Noregur & Svíbjóđ & Î́sland \\
\hline Undurbúa ríkisstjórnarfundi & $\bullet$ & $\bullet$ & $\bullet$ & $\bullet$ & $\bullet$ \\
\hline Upplýsa um stefnu stjórnvalda & O & O & $\bullet$ & O & $\bullet$ \\
\hline $\begin{array}{l}\text { Mannauđsstefna fyrir } \\
\text { opinbera geirann }\end{array}$ & $\square$ & $\square$ & $\square$ & $\square$ & $\square$ \\
\hline Umbætur í opinberum rekstri & O & O & $\square$ & $\square$ & 0 \\
\hline Stefnumótun / Áætlanagerđ & O & $\bullet$ & O & $\bullet$ & O \\
\hline $\begin{array}{l}\text { Áhættustjórnun / } \\
\text { stefnumótandi framsýni }\end{array}$ & O & O & O & $\bullet$ & $\bullet$ \\
\hline $\begin{array}{l}\text { Undirbúa áætlun um } \\
\text { stjórnarstefnuna }\end{array}$ & $\bullet$ & O & O & $\bullet$ & $\bullet$ \\
\hline Mótun stefnuvalkosta & O & $\square$ & O & O & O \\
\hline Stefnugreining & O & O & O & O & O \\
\hline Samhæfing & $\bullet$ & $\bullet$ & O & O & $\bullet$ \\
\hline Gæđi og samræmi við lagasetningu & O & $\square$ & $\square$ & O & $\bullet$ \\
\hline Vöktun með framkvæmd stefnumála & O & $\bullet$ & $\square$ & O & O \\
\hline Samskipti við sveitastjórnir & O & $\square$ & $\square$ & $\square$ & $\square$ \\
\hline Samskipti við ping & O & $\bullet$ & O & O & $\bullet$ \\
\hline Próunarsamvinna & $\square$ & $\square$ & $\square$ & $\square$ & $\square$ \\
\hline $\begin{array}{l}\text { Samhæfa stefnu gagnvart } \\
\text { yfirpjóðlegum stofnunum }\end{array}$ & $\bullet$ & O & $\square$ & O & $\square$ \\
\hline $\begin{array}{l}\text { Undirbúningur fyrir innkomu } \\
\text { nýrra ríkisstjórna }\end{array}$ & $\bullet$ & $\bullet$ & $\bullet$ & O & $\bullet$ \\
\hline
\end{tabular}

- Á ábyrgð miðlægrar stjórnunareiningar

O Ábyrgð deilt á milli miðlægrar stjórnunareiningar og annarra aðila

$\square$ Ábyrgð liggur annars staðar 
Evrópusambandið hefur greint prjú pemu pegar pað kemur að verkefnum og áherslum stjórnkerfismiðja. Í fyrsta lagi forysta og yfirsýn en forsætisráðherra er jafnan sá aðili sem almenningur telur að beri ábyrgð á frammistöðu stjórnvalda hverju sinni, hvort sem kveðið er á um slíkt í lögum eða ekki. Dað er de facto skylda stjórnkerfismiðja að setja kúrsinn, vera metin af verkum sínum, stýra skipinu fram hjá peim hindrunum sem pað mætir á leiðinni og upplýsa um framgang mála. Í öđru lagi samhæfing pvert á ráouneyti en opinber stjórnsýsla er jafnan skipulögð í lóðrétt stjórnunarform, par sem sérhæfing á tilteknum sviðum er mikil. Hins vegar er lárétt nálgun oft nauðsynleg við lausn mála og fyrir vikið ákveða stjórnvöld að fela stjórnkerfismiðjum að leiða slíka vinnu. Í priðja lagi skilvirkni innan stjórnsýslunnar en pað eru ýmis verkefni, eins og að stýra miðlægum rekstrareiningum, setja staðla, viðmið og eiga samskipti við ping par sem pað er einfaldara, skynsamara og hagkvæmara ef slíkt er gert af einum aðila en ekki allri stjórnsýslunni (European Commission 2017).

\subsection{Skipulag og mannauður stjórnkerfismiðja}

Stjórnkerfismiðjur eru jafnan litlar, en pær purfa pó mannskap sem tryggir að pær geti rækt skyldur sínar. Đær purfa að vera sveigjanlegar til að geta brugðist við og aðlagað sig nýjum áskorunum. Meginreglan er sú að stjórnkerfismiðjur eiga ekki að veita tiltekna pjónustu beint eða leiða tiltekna fagmálaflokka, nema pá mögulega pjónustu er varðar aðra aðila innan stjórnsýslunnar par sem skynsamlegt er að stýra pjónustunni með peim pætti (OECD 2018). Meðal OECD ríkja má finna nokkur pverfagleg stefnumál á ábyrgð stjórnkerfismiðja, sjá mynd 1. Á Íslandi leiðir forsætistáðuneytið hluta pessara stefnumála sem og fjármála -og efnahagsráðuneytið.

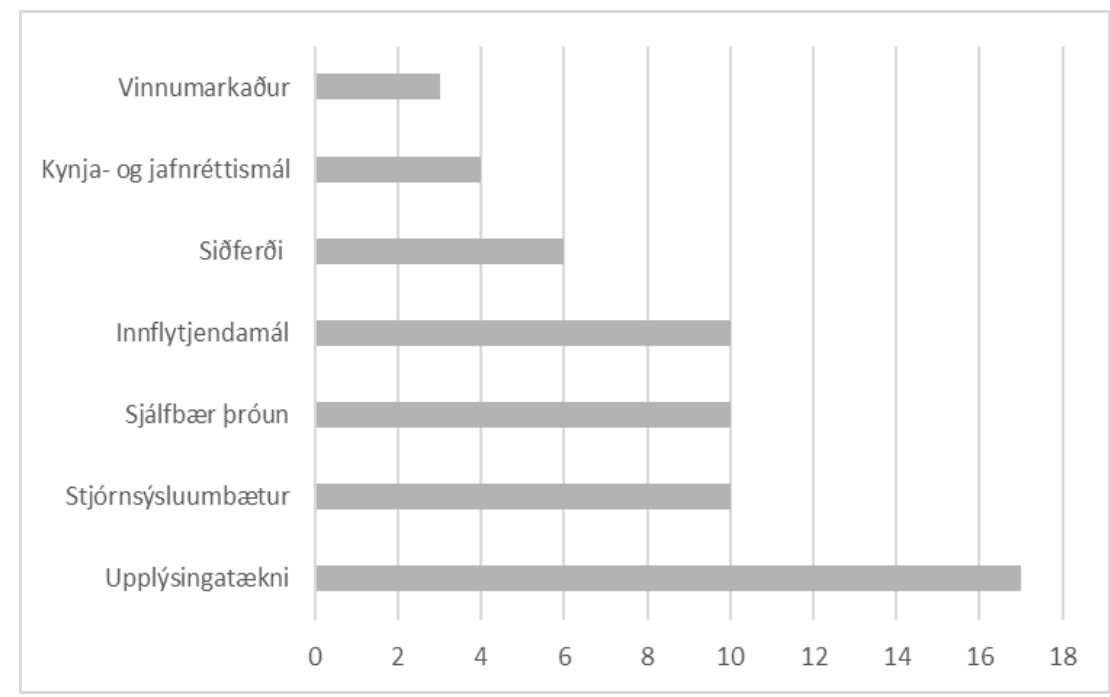

Mynd 1. Helstu stefnumál sem leidd eru af stjórnkerfismiðjum innan aðildarríkja OECD (OECD 2018) 
Verkefni stjórnkerfismiðja takmarkast sjaldan við eina deild eða eina skrifstofu. Almennt eru verkefni unnin innan hverrar skrifstofu fyrir sig og er sótt í pekkingu pvert á skrifstofur ráðuneytisins ef pörf krefur. Hin leiðin, felur í sér teymisvinnu par sem að hverju verkefni koma aðilar frá öllum skrifstofum sem teljast til stjórnkerfismiðju. Рað eru kostir og gallar sem fylgja mismunandi skipulagi, hættan við teymisvinnuna er sú að par geta komið aðilar saman sem hafa e.t.v. lítið fram að færa í sumum tilfellum. Svo er hættan á að par sem unnið er að verkefnum á hverri skrifstofu fyrir sig, gleymist að leita að sérfræðingum sem virkilega geta lagt eitthvað af mörkum.

Ef stjórnkerfismiðja er pátttakandi í verkefni skiptir máli að hlutverk hennar og ábyrgð sé skýr meðal annarra ráðuneyta og hagsmunaaðila. Einingin parf einnig að vera sveigjanleg svo að hún geti brugðist hratt við ef pörf krefur. Stöðugleiki stjórnkerfismiðja við stjórnarskipti felast t.a.m. í pví að viðhalda stofnanaminni, tryggja að farið sé að peim ferlum sem búið er að marka og móta áætlanir við langtíma áskorunum. Sveigjanleikinn felst einnig í pví að geta aðlagað sig að nýrri stjórnarstefnu skjótt og geta hafið strax störf með nýjum stjórnarherrum o.s.frv. (European Commission 2017).

Stjórnkerfismiðja parf að hafa skýran lagagrundvöll, fjármuni og starfsmenn en umfram allt parf svona eining pólitískt lögmæti. Рað parf að vera skýrt að stjórnkerfismiðja tali og framkvæmi í nafni oddvita ríkisstjórnarinnar (e. Head of Government). Ekki má gera lítið úr hlutverki starfsmanna stjórnkerfismiðja, peir purfa bæði að hafa góða pekkingu og reynslu innan stjórnkerfisins en jafnframt geta aðlagað sig að nýjum verkefnum eða umhverfi með skjótum hætti. Prátt fyrir að stjórnkerfismiðjur njóti lögmætis, purfa starfsmenn pess að geta sannfært pá sem peir eiga í samskiptum við, samið við aðila, miðlað málum og veitt leiðbeiningar sem krefst skilning á stjórnmála- og stjórnsýslumenningu hverju sinni (European Commission 2017).

\section{Frá nýskipan að samhentri stjórnsýslu}

Íslenska stjórnsýslan á rætur að rekja til evrópskra skrifræðishefða en pær hugmyndir sem hún grundvallast á eru að mestu leyti fengnar frá Danmörku. Skrifræðið náði hins vegar veikari fótfestu hér á landi og hefur íslensk stjórnsýsla verið losaralegri en danska fyrirmyndin sem hún grundvallast á (Gunnar Helgi Kristinsson 1999). Víðast hvar í Evrópu er framkvæmdavaldið elsti hluti ríkisvaldsins en á Íslandi fékk Alpingi takmarkað löggjafarvald með stjórnarskránni 1874 og innlent framkvæmdarvald kom ekki til skjalanna fyrr en árið 1904. Afleiðing pessa varð sú að íslenska framkvæmdarvaldið hefur haft veikari stöðu gagnvart löggjafanum en tíðkast hefur í nágrannaríkjunum (Gunnar Helgi Kristinsson o.fl. 1992). Íslenska stjórnsýslukerfið var og er að hluta til enn byggt pannig upp að ráðuneytin eru lítil en stofnanirnar margar. Mörg smá ráðuneyti hafa í gegnum tíðina haft veikar forsendur til að sinna yfirstjórn stofnana, s.s. að tryggja að pær búi við hagkvæmt skipulag, nauðsynlega hæfni og mannauð (Gunnar Helgi Kristinsson \& Pétur Berg Matthíasson 2014).

Nýskipan í ríkisrekstri má skoða sem andsvar við hefðbundnum hugmyndum um opinbera stjórnsýslu. Nýskipanin sem hugmyndafræði náði mikilli útbreiðslu í upphafi níunda áratugarins. Með henni var áhersla lögð á nýjar hugmyndir um viðskipti 
og stjórnun í opinberum rekstri par sem meðal annars var leitað í smiðju markaðshugmynda. Hvatakerfi áttu að losa hið opinbera undan reglufargani og skuldaklafa. Innleiðing nýskipunar á níunda og tíunda áratugnum leiddi til pess að stofnanir í opinbera geiranum voru brotnar upp, búnar voru til einsleitnari stofnanir með færri hlutverk, sem hver fyrir sig áttu að leitast við að ná skýrum markmiðum. Með fjölgun slíkra stofnana varð stjórnvöldum ljóst að pau áttu orðið erfitt með samhæfingu, að fá opinbera aðila til að vinna saman að sameiginlegum markmiðum. Pessu fylgdi meðal annars laustengdari stjórnunarform milli æðri og lægri prepa stjórnsýslunnar. Við pað varð ábyrgð stjórnmálamanna óskýrari og peim gert erfitt fyrir að stýra pessum stofnunum. (Pollitt \& Bouckaert 2011).

Á tíunda áratugnum hóf fjármálaráðuneytið á Íslandi átak undir kjörorðinu „,nýskipan í ríkisrekstri“ og sampykkti ríkisstjórnin stefnu pess efnis árið 1995. Mikið var lagt upp úr sjálfstæði eininga og valddreifingu innan opinberrar stjórnsýslu. Đessi stefna markaði nokkur tímamót par sem í fyrsta skiptið var sett fram heildstæð stefna um áherslur og stjórnun í rekstri ríkisins. Markmiðin með pessum breytingum voru að mestu leyti pau sömu og hjá öðrum OECD-ríkjum sem höfðu tileinkað sér pessa stefnubreytingu. Рað er meiri dreifstýring í ákvarðanatöku, endurskipulagning ríkisfjármála, aukin áhersla á frammistöðumöt og frammistöðustaðla, minna reglufargan, pjónustusamningar og aukinn einkarekstur (Ómar H. Kristmundsson 2003).

Áhrifa af umbótastefnu stjórnvalda á tíunda áratugnum gætti vel inn á miðjan 1. áratug pessarar aldar með innleiðingu ýmissa aðferða í anda stefnunnar, s.s. útvistunarstefnu, aukinnar áherslu á einkaframkvæmd og opinbera hlutafélagavæðingu. Með nýskipaninni veiktist umboðskeðjan sem leiddi til minna aðhalds gagnvart stofnunum. Var par verið var að færa hluta af hinum opinbera rekstri fjær kjarna framkvæmdarvaldsins yfir til meira eða minna sjálfstæðra aðila. Fyrir vikið reyndist erfitt fyrir stjórnmálamenn að fylgjast með framkvæmdinni. Valddreifingin sem fólst í nýskipaninni torveldaði yfirsýn og kallaði fram spurningar um ábyrgð ráðherra pegar peir hafa ekki raunverulega stjórn á peim aðilum sem sýsla með verkefni hins opinbera (Gunnar Helgi Kristinsson 2007; Gunnar Helgi Kristinsson \& Pétur Berg Matthíasson 2014).

Pollitt og Dan (2013) gerðu ítarlega greiningu á yfir 500 fræðigreinum og rannsóknum á áhrifum nýskipunar í opinberum rekstri til að skoða hvort árangurstengdar umbætur hefðu leitt til breytinga á afurðum og árangri. Niðurstaðan var sú að prátt fyrir fjölda fræðigreina um viðfangsefnið voru mjög fáar góðar rannsóknir sem beindu sjónum að afurðum, og enn færri fengust við árangur. Einnig greindu peir Pollitt og Dan (2013) að áhrif umbótanna væru mjög ólík, stundum varð breyting á afurðum og árangri mjög takmörkuð eða til hins verra. Rannsókn peirra gefur til kynna að almennt séu rannsóknir á áhrifum umbóta frekar brotakenndar. Nýskipan hefur sætt gagnrýni ekki síst vegna pess að margar af peim breytingum sem gerðar hafa verið í nafni hennar voru innleiddar án pess að gæta að pví hvaða áhrif pær höfðu á gildi og venjur sem einkenna opinbera stjórnsýslu (OECD 2005).

Pendúll stjórnsýsluumbóta hefur verið að færast á síðustu tveimur áratugum frá pví umbroti sem nýskipan í opinberum rekstri leiddi af sér í átt að eflingu samhæfingar 
innan stjórnsýslunnar. Samhæfing er mjög ofarlega á dagskrá í mörgum Evrópuríkjum og nú á tímum par sem verkefnin eru æ flóknari og ekki lengur afmörkuð eru gerðar sífellt meiri kröfur um samstarf og samhæfingu fjölda aðila við lausn peirra (Lægreid \& Christensen 2019). Á Íslandi virðist gildi samstarfs og samráðs innan stjórnsýslunnar hafa orðið undir við innleiðingu nýskipunar í ríkisrekstri. Sjálfstæði stofnana hér á landi veikti forsendur ráðuneyta til að gegna pessu hlutverki sínu og í sumum tilvikum virtust ráđuneytin telja óljóst í hverju pær fólust. Nýlegar úttektir OECD á stjórnsýslu Finna, Íra og Eistlendinga benda til pess að æ fleiri lönd séu að átta sig á pessum veikleikum nýskipunar í ríkisrekstri og að ríkur vilji sé til að taka á peim vanda sem upp er kominn vegna skorts á samráði og samstarfi innan opinbera kerfisins (Forsætisráðuneytið 2010a; OECD 2008; OECD 2010a; OECD 2010b).

\subsection{Leiðir til að efla stjórnkerfismiðjur}

Hvað kann að skýra mismunandi próun stjórnkerfismiðja? Stærð, skipulag og hlutverk stjórnkerfismiðja er mjög breytilegt eftir ríkjum og pað virðist oft fara eftir stöðu og áherslum leiðtoga eða oddvita ríkisstjórnar (e. Head of Government) hverju sinni. Hvernig hefðir og löggjafarmenning hafa mótað stjórnkerfismiðjur kann ýmist að styrkja pær eða veikja en einn páttur í áhrifum stjórnkerfismiðja er að pær geti talað fyrir hönd oddvitans pannig að önnur ráðuneyti taki mark á. Hood (1991, 1995) skoðaði ólíka pætti sem kynnu að skýra umbótaviðleitni sumra og tregðu annarra ríkja við innleiðingu nýskipunar. Ýmsar ástæður voru skoðaðar, eins og hvort stjórnmálin skipti máli, p.e.a.s. hvar stjórnarflokkar voru staðsettir á hægri-vinstri ás stjórnmálanna? Hvort ólík efnahagsleg frammistaða ríkja hafi áhrif á umbótaviðleitni peirra eða stærð hins opinbera? Hood komast að pví að ekkert af pessu skýri að fullu hvers vegna sum ríki innleiði umbætur. Hood (1995) leitaði helst svara í pví að skoða tilefni og tækifæri; að ríki sem innleiði frekar umbætur hjá sér séu pau sem hafi tilefni og tækifæri á tilteknum tíma.

Đær rannsóknir sem gerðar hafa verið á próun stjórnkerfismiðja gefa til kynna að fjölgun peirra megi rekja til tveggja pátta. Annars vegar eðli peirra áskoranna sem mörg stjórnvöld standa frammi fyrir sem ganga pvert á hefðbundnar línur ráđuneyta og krefjast aukinnar samvinnu og samhæfingu aðgerða til að mæta peim (Clarke \& Stewart 1997; OECD 2018). Hins vegar má rekja eflingu stjórnkerfismiðja til peirra próunar sem átti sér stað með tilkomu nýskipunar í ríkisrekstri, p.e. aukinni valddreifingu til stofnana og dreifðari ákvörðunartöku. Slík próun dró úr getu stjórnvalda til að stýra verkum innan kerfisins (Dahlström, Peters \& Pierre 2011).

Ríki hafa farið ólíkar leiðir til að styrkja stjórnkerfismiðjur. Ríki sem eru talin hafa gengið hvað lengst til að ná aftur völdum til að styrkja miðjuna eru engilsaxnesku ríkin (Ástralía, Bandaríkin, Kanada og Bretland). Pau hin sömu gengu sum hver langt í að veikja miðjuna á tíma nýskipunar í ríkisrekstri. Skandinavísku ríkin (Svípjóð, Danmörk og Finnland) gengu skemur en pau engilsaxnesku. Napóleónsk (Frakkland og Ítalía) og germönsk ríki (Dýskaland) gengu skemmst og fóru sér mun hægar við dreifingu valds á nýskipunartímabilinu (Dahlström, Peters \& Pierre 2011).

Rannsóknir á leiðum ríkja til að styrkja miðjuna gefa til kynna að pað séu stjórnkerfis- 
legar skýringar sem geta haft áhrif á hvaða leið er valin. Jafnframt kunna aðstæðurnar að vera mismunandi pó að í meginatriðum megi rekja pær til framangreindra pátta. Greining Dahlström, Peters og Pierre (2011) leiddi í ljós prjár leiðir til að styrkja miðjuna. Í fyrsta lagi með pví að styrkja pólitísk áhrif innan framkvæmdavaldsins, en petta var m.a. gert með fjölgun ráðgjafa/aðstoðarmanna. Í öðru lagi, með pví að styrkja samhæfingarhlutverk miðjunnar lárétt innan kerfisins. Í priðja lagi með pví styrkja samhæfingarhlutverk miðjunnar lóðrétt innan kerfisins sem felst m.a. í markvissari eftirfylgni með málum.

\section{Pólitiskir rádgjafar}

Sum staðar hefur mátt greina fjölgun í ráðningu pólitískra aðstoðarmanna. Fjöldi pólitískra ráđgjafa hefur aukist í nokkrum lýðræðisríkjum, ekki aðeins peim sem teljast til germönsku eða napóleónsku stjórnsýsluhefðanna heldur einnig meðal ríkja engilsaxnesku stjórnsýsluhefðarinnar og í Skandinavíu en báðar pessar hefðir hafa jafnan verið með færri pólitískt skipaða ráðgjafa. Í Svípjóð hefur verið stórkostlegur vöxtur í fjölda pólitískra ráđgjafa frá pví snemma á áttunda áratugnum, frá um tugum pólitískra ráđgjafa í næstum tvö hundruð, sem náði hámarki árið 2006. Falldin ríkisstjórnin 1973-1976 réð næstum tvisvar sinnum fleiri ráðgjafa en fyrri stjórn. Pessi breyting á sér líklega tvennar skýringar. Í fyrsta lagi var vaxandi pörf fyrir lárétta samhæfingu innan ríkisstjórnarinnar vegna fjölda flokka sem tóku pátt. Til að leysa petta samræmingar vandamál innan ríkisstjórnarinnar voru stofnaðar pólitískar samhæfiseiningar í hverju ráđuneyti, hvert með nokkrum pólitískum ráðgjöfum. Annar páttur var vaxandi pörf fyrir lóðrétta samhæfingu með tilkomu nýrrar samsteypustjórnar. Баð sama gerðist í Bretlandi með tilkomu ríkisstjórnar Tony Blair árið 1997 en við pað fjölgaði pólitískum ráðgjöfum og peir urðu $æ$ mikilvægari (Dahlström, Peters \& Pierre 2011).

\section{Lárétt sambafing}

Dörfin fyrir lárétta samhæfingu er áberandi í flestum ríkjum og lýsir sér vanalega í pví að pað eru valdaátök á milli forsætisráðuneyta og annarra ráðuneyta (fagráðuneyta). Til að mæta pessari áskorun er reynt að bæta samhæfinguna sem felst í bví að styrkja stjórnkerfismiðjuna í forsætisráðuneytinu sem gefur pá forsætisráðherra betri yfirsýn og tækifæri til að hafa áhrif á starfsemi annars staðar í kerfinu. Í Bretlandi rakst ríkisstjórn Tony Blairs fljótlega á vegg pegar sundurleit samhæfing ásamt sterkum ráðuneytum leiddi til pess að stefnan varð mótsagnakennd og hún úr tengslum við heildarstefnuna. Tony Blair brást við með pað að markmiði að tryggja að áherslur og stefnur ráðuneyta yrðu betur tengdar heildarstefnunni. Рað tókst hins vegar ekki að sigrast á sílóum ráðuneyta og par af leiðandi ákvað Tony Blair að einbeita sér að pví að styrkja stjórnkerfismiðjuna og bæta framkvæmd (Dahlström, Peters \& Pierre 2011).

Reynt hefur verið að koma á lárétti samhæfingu í fleiri ríkjum með ólíkum útfærslum. Í Ástralíu, öðru engilsaxnesku ríki, hafa nokkrar leiðir verið farnar. Í fyrsta lagi hefur forsætisráðherra sett mál í forgang sem ganga pvert á önnur ráðuneyti. Í öðru lagi hafa verið settir ferlar til að auka samhæfingu, auk nýrra nefnda og verkefnahópa. Í priðja lagi voru settar fram tillögur um hvernig ætti að afgreiða mál sem ganga pvert á nokkur ráðuneyti. 
Bæði í Danmörku og Finnlandi vilja menn rekja eflingu miðlægra eininga til stuðnings forsætisráðherra. Í Finnlandi tók Matti Vanhanen við sem forsætisráðherra árið 2003. Umbreytingin í Finnlandi hafði pó hafist kjörtímabiliðá undan í stjórn Lipponens pegar Finnar gerðu umtalsverðar breytingar á stjórnarskrá sinni og drógu úr valdi forsetans. Раð skipulag sem sett var á fót í Finnlandi til að styðja við aðgerðir stjórnkerfismiðju skiptir máli. Kerfið var byggt pannig upp að ábyrgð ráðamanna og embættismanna var skilgreind, auk pess voru stjórntæki ítarlega útfærð, fyrirkomulag eftirfylgni, funda og samsetning nefnda. Í Finnlandi voru jafnan skilgreindar nokkrar áætlanir (e. programmes) s.s. um atvinnumál, frumkvöðla- og nýsköpunarmál, upplýsingatækni o.s.frv. Pessar áætlanir voru jafnan leiddar af samhæfingarráðherra. Баð gat verið ráðherra sem málaflokkurinn féll að stórum hluta undir. Samhæfingarráðherra fyrir tiltekna áætlun fékk ekkert umfram vald en gat pó lagt fram tillögur um fjárveitingar til verkefna á valdsviði annars ráðherra (Dahlström, Peters \& Pierre 2011).

Kerfið í Danmörku er nokkuð flóknara, en parlent stjórnkerfi var nokkuð valddreift fyrir nýskipan í ríkisrekstri. Kerfið býður upp á mikla sjálfsstjórn meðal ráðuneyta og í dönsku stjórnarskránni kveður svo á um að að pegar ráðherrar hafi einu sinni verið tilnefndir af forsætisráðherra séu peir pólitískt og löglega ábyrgir fyrir ráðuneytum sínum, skipulagi og stjórnsýslu. Kerfið einkennist af pólitískt flóknum og sterkum svæðisbundnum strúktur og fyrir vikið er pað áskorun að samræma stefnumótun og samhæfingu í ríkisfjármálum. Anders Fogh Rasmussen sem tók við sem forsætisráðherra í Danmörku árið 2001 braut á bak aftur mjög sterkt miðlægt hlutverk fjármálaráðuneytis sem hafði verið á próast á tíunda áratugnum. Við pað varð breyting á valdajafnvæginu með tilkomu samhæfingarnefndar sem forsætisráðherrann fór fyrir (Dahlström, Peters \& Pierre 2011).

\section{Lódrétt sambafing}

Einn liður í að styrkja stjórnkerfismiðjuna er með lóðréttri samhæfingu sem felur í sér hæfni til að gera úttektir og fylgja eftir málum. Eins og svo oft áður voru pað engilsaxnesku ríkin sem tóku forystu. Ein mikilvægasta próunin í Bretlandi var styrking stjórnkerfismiðjunnar með stofnun framkvæmdareiningar (Delivery Unit) (PMDU). Petta var mikilvæg nýjung á öðru kjörtímabili Verkamannaflokksins sem miðaði að pví að fá pá til að efna loforð sín í auknum mæli. PMDU var ætlað að tryggja að lykilmarkmið forsætisráðherrans næðust með pví að einbeita sér að pví hvað önnur ráđuneytin voru að gera til að ná markmiðum stjórnvalda (Barber 2016). Einn páttur í eflingu samhæfingarferilsins í Finnlandi fólst í pví að bæta eftirfylgni með framkvæmd mála. Með áætlun stjórnvalda (e. Government Strategy Document, GSD) var slíku fyrirkomulagi komið á en meginframkvæmdaaðili áætlunarinnar var stjórnkerfismiðja forsætisráðherrans í Finnlandi. Í áætluninni voru markmið um árangur stefna og verkefna og hvernig mæla átti pau. Jafnframt voru mælikvarðar til að fylgjast með próun helstu stefnumála stjórnvalda (Dahlström, Peters \& Pierre 2011).

Rannsóknir á próun mála í engilsaxnesku ríkjunum og í Skandinavíu gefa til kynna að efling stjórnkerfismiðju sé meiri í engilsaxnesku ríkjunum pó Svípjóð kunni vissu- 
lega að vera undantekning. Jafnframt virðist efling stjórnkerfismiðja vera mest hjá peim ríkjum sem gengu hvað lengst í að draga úr völdum miðjunnar á tímum nýskipunar í ríkisrekstri. Dróunin meðal aðildarríkja OECD gefur til kynna að verið sé að styrkja stjórnkerfismiðjur, p. á m. á Íslandi, en í um 67\% aðildarríkja hefur bæði orðið fjölgun á starfsfólki auk pess sem fjárveitingar til starfseminnar hefur hlutfallslega aukist, sjá nánar mynd 2. Engin breyting hefur orðið á starfsfólki í um fjórðungi ríkjanna og engin breyting á fjárveitingum í um fimmtungi ríkjanna. Fækkun starfsfólks og lækkun fjárveitinga hefur orðið í um 10-15\% ríkjanna (OECD 2018).

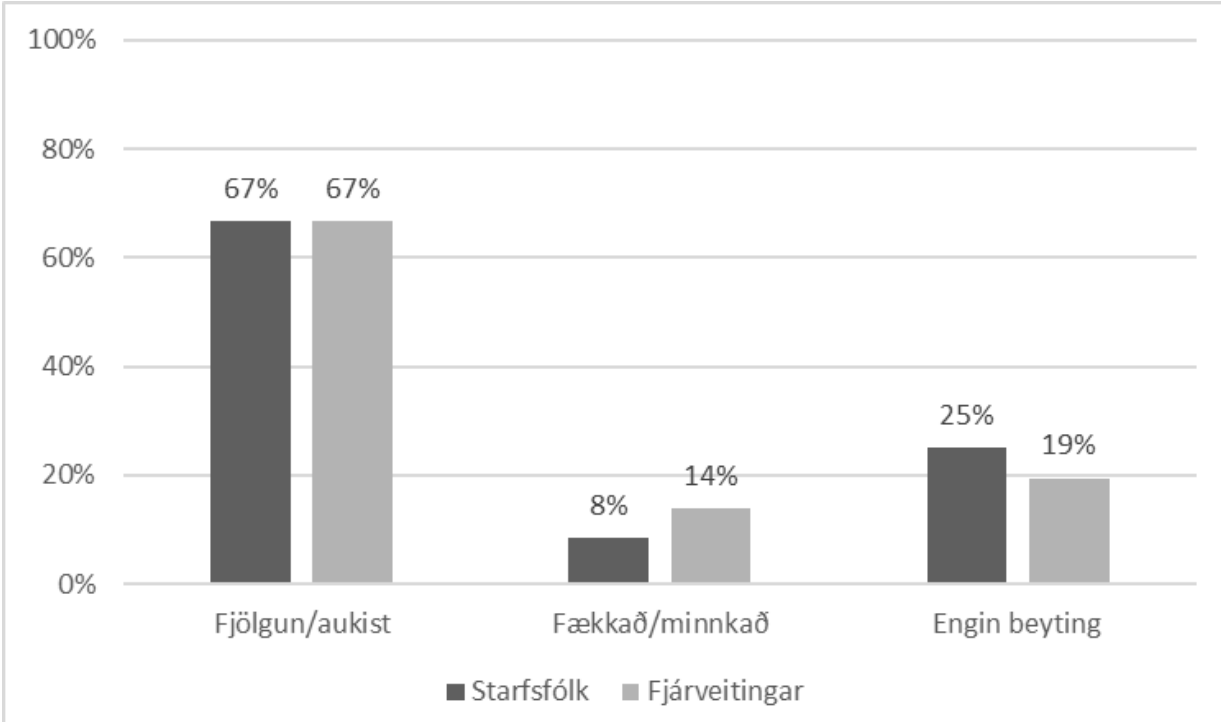

Mynd 2. Próun starfsfólks og fjárveitinga innan stjórnkerfismiðja OECD ađildarríkja á milli áranna 2012 og 2016

\section{Verkstjórnar- og samhæfingarhlutverk forsætisráđuneytisins}

Баð var ekki fyrr en í kjölfar fjármálakrísunnar 2008 á Íslandi að farið var að ræða opinberlega um hlutverk forsætisráðuneytisins sem verkstjórnar- og samhæfingarráduneytis. Árið 2009 fékk forsætisráðuneytið aukið forystu- og samhæfingarhlutverk innan Stjórnarráðsins með breytingum sem pá voru gerðar á reglugerð um Stjórnarráð Íslands. Með pessu var forsætisráðuneytinu falin verkstjórn með skýrari hætti en áður innan Stjórnarráðsins sem fólst í pví að samhæfa störf ráðherra og ráðuneyta. Samhliða breytingunni voru svokallaðir ráðuneytisstjórafundir settir í fastara form undir forystu ráðuneytisstjóra forsætisráðuneytisins. Pessir fundir geta myndað vettvang til að ræða sameiginleg mál, skiptast á upplýsingum og samhæfa vinnubrögð enda sé pá að pví hugað að móta starfsemi peirra með skýrri verkstjórn og festu í vinnubrögðum (Forsætisráðuneytið 2010b). 
Með skýrslunni Samhent stjórnsýsla sem kom út árið 2010 er enn fremur tekið undir petta enda heilmikil umfjöllun um hlutverk forsætisráðuneytisins og hvernig pað purfi að breytast og styrkjast sem verkstjórnaraðili. Í skýrslunni er einnig vikið að úttekt OECD á finnsku stjórnsýslunni um mikilvægi pess að forsætisráđuneyti og fjármálaráđuneyti vinni vel saman. Fram kemur hjá nefndinni sem stóð að skýrslunni að hún telji að lýsingin á finnska kerfinu eigi að mörgu leyti vel við á Íslandi (Forsætisráðuneytið 2010a). Dar segir um Finnland:

Forsætisráðuneytið gegnir lykilhlutverki við að ná samstöðu innan stjórnsýslunnar um framkvæmd stefnu stjórnvalda á hverjum tíma. Sem kjarni miðlægs framkvæmdarvalds parf ráðuneytið að spila stærri pátt í pví að stýra og samhæfa stjórnsýslu ríkisins. [...] Par sem forsætisráðuneytið ber ábyrgð á stefnumörkun og pví að horfa fram veginn parf pað að vera virkt í pví hlutverki, en ekki eingöngu bregðast við upplýsingum frá öðrum. Áhrif pessa kjarna miðlæga framkvæmdarvaldsins byggist líka á samspili og dreifingu verkefna milli ráđuneyta sem pað mynda - í Finnlandi er um að ræða fjármálaráðuneytið og forsætisráðuneytið.

Skrifstofa umbótamála í fjármálaráðuneytinu vinnur vel með forsætisráđuneytinu og einnig starfsmannaskrifstofan [...] Aftur á móti hættir fjárlagaskrifstofu fjármálaráðuneytisins til að vinna ein án tengsla við aðra. Hvað petta varðar er mikill fjárlagakúltúr (e. strong budget culture) í stjórnsýslunni og skortir á að forsætisráðuneyti komi skýrri stefnu inn í pá vinnu (OECD 2010a, 20).

Раð er óhjákvæmilegt og jafnframt eðlilegt að málefni sem upp koma geti varðað ólíkar skrifstofur í ólíkum ráðuneytum. Verkefni forsætisráðuneytisins og fjármálaráðuneytisins skarast reglulega og hvernig pau leysa úr peim gefur vísbendingu um hvernig gengur að framfylgja ýmsum viðamiklum áherslum ríkisstjórnarinnar hverju sinni. Ekki má gera lítið úr samræmingar- og samhæfingarhlutverki fjármála- og efnahagsráðuneytisins varðandi skipulag og starfshætti, almennar umbætur, innkaup, eignarmál, nýsköpun, opinber fjármál o.fl. Nokkuð viðamikil breyting var gerð á hlutverki ráðuneytisins í byrjun árs 2016 pegar lög um opinber fjármál nr. 123/2015 tóku gildi. Deim var ætlað að efla hagstjórnarhlutverk ráðuneytisins og tryggja heildarsýn yfir próun opinberra fjármála. Gerð fjármálaáætlunar krefst umtalsverðrar samræmingar, m.a. í tengslum við fjárhagsmarkmið sveitarfélaga. Með lögunum var markmiðið að festa betur í sessi samræmingu milli ríkisaðila (og sveitarfélaga) og opinberra fyrirtækja m.a. til að koma í veg fyrir ósamræmi í hagstjórn.

Hlutverk forsætisráðuneytisins sem verkstjórnar- og samhæfingaraðili var skilgreint í nýjum heildarlögum um Stjórnarráo Íslands nr. 115/2011. Í peim er í hvívetna vísað 
til verkstjórnar- og samhæfingarhlutverks ráđuneytisins. Í 8. gr. laganna er annars vegar kveðið á um skyldu forsætisráðherra til að stuðla að skýrri verkaskiptingu á milli ráðherra. Hins vegar skyldu hans til að aðstoða ráðherra við samhæfingu stefna og aðgerða pegar málefni og málefnasvið skarast (Lög um Stjórnarráð Íslands nr. 115/2011).

Fagskrifstofur forsætisráðuneytisins hafa allar ákveðið samræmingar- og samhæfingarhlutverk gagnvart öðrum ráðuneytum eða stofnunum. Skipurit forsætisráðuneytisins, sjá að neðan, gefur góða mynd af helstu verkefnunum. Umboð skrifstofanna er hins vegar breytilegt, t.a.m. er pað mjög skýrt hvert hlutverk yfirstjórnar er pegar kemur að málefnum ríkisstjórnarinnar og um pað gilda reglur sem ráðuneytin purfa að fylgja. Баð sama má segja um lagaskrifstofuna sem hefur miðlægt vald er lýtur að umsýslu og eftirliti með efnislegum gæðum frumvarpa. Ýmis verkefni stefnuskrifstofu er varðar eftirfylgni og samhæfingu eru meira unnin ad-hoc. Um jafnréttismálin er lagaramminn nokkuð skýr og er par jafnframt stofnun sem fylgir eftir ýmsum málum. Verkefni skrifstofu fjármála eru aftur á móti sambærileg verkefnum annarra slíkra skrifstofa í öðrum ráðuneytum og pví með takmarkaðra samræmingarhlutverk pvert á Stjórnarráðið.

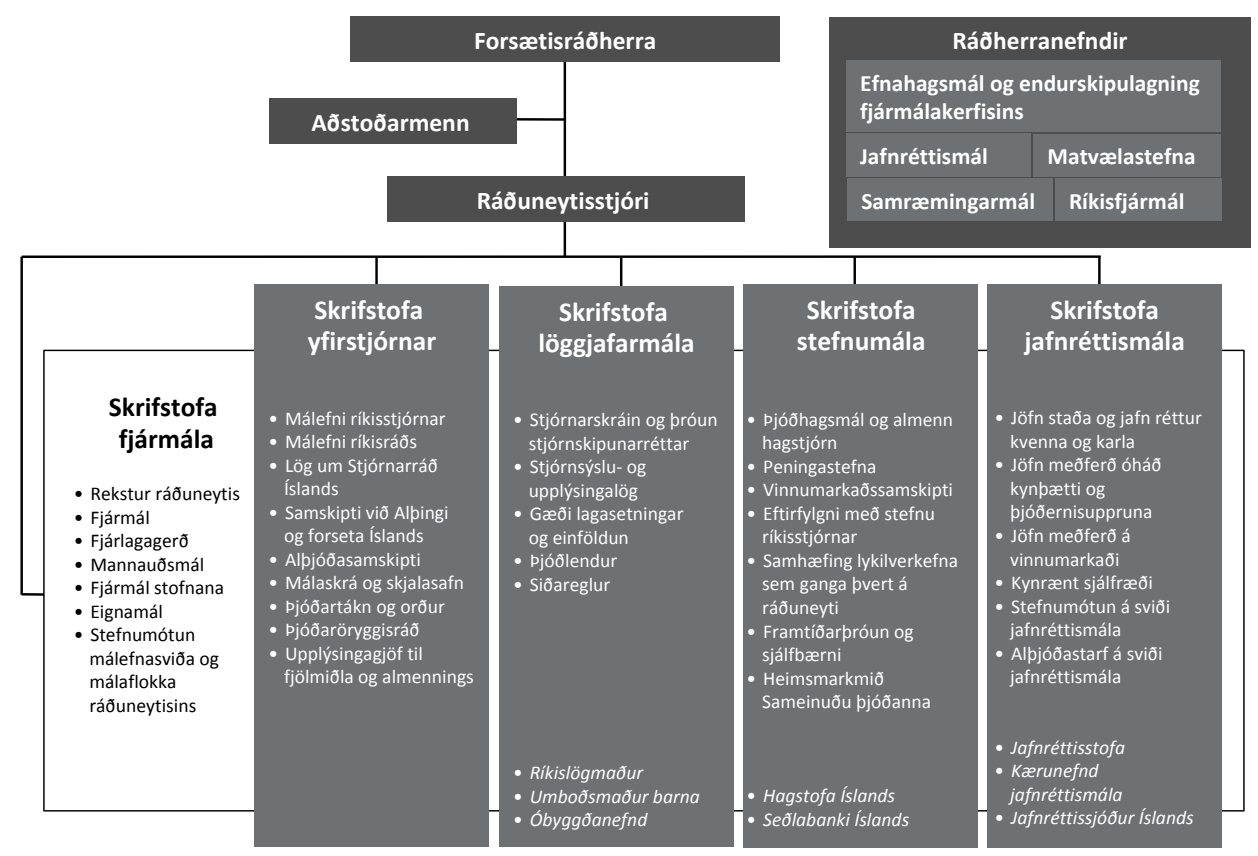

Mynd 3. Skipurit forsætisráđuneytisins 2019

\subsection{Sterkari miðja með markvissari samhæfingu og eftirfylgni}

Hugmyndafræðin um mikilvægi sterkrar stjórnkerfismiðju var sett fram í skýrslunni Sambent stjórnsýsla. Pví verður ekki svarað hér hvers vegna Íslandi fór seinna af stað en önnur ríki að styrkja miðlæga einingu. Eins og fram hefur komið eru ýmsar kenningar í 


\section{STJÓRNSÝSLA}

fræðunum sem m.a. telja petta viðbrögð sumra ríkja við afleiðingum pess að ganga of langt við innleiðingu nýskipunar í ríkisrekstri. Jafnframt purfi að vera tilefni og tækifæri til breytinga (Hood 1995). Ísland var í seinni bylgjunni að taka upp nýskipunina og pví kannski eðlilegt að Ísland hafi einnig verið seinna til að huga að sterkari miðju.

prjár aðferðir hafa jafnan verið notaðar af ríkjum til að styrkja stjórnkerfismiðju, 1) að fjölga pólitískum ráðgjöfum/aðstoðarmönnum, 2) bæta samhæfingu og 3) bæta eftirfylgni. Forsætisráðuneytið á Íslandi hefur frekar, líkt og Danir og Finnar höfðu áður gert, innleitt ýmsar aðferðir til að bæta samhæfingu og eftirfylgni. Hins vegar fóru Svíar að einhverju leyti aðra leið en hinar Norðurlandapjóðirnar. Peir hafa hægt og bítandi verið að bæta við pólitískum aðstoðarmönnum sem koma tímabundið inn í stjórnsýsluna (Dahlström, Peters \& Pierre 2011).

Í grein Gests P. Reynissonar og Ómars H. Kristmundssonar (2014) um hverjir verða aðstoðarmenn kemur fram að hið pólitíska aðstoðarmannakerfi innan Stjórnarráðs Íslands hafi fest sig í sessi eftir að slíkar ráoningar voru heimilar með lögum um Stjórnarráð Íslands árið 1969. Skipta peir tímabilinu í prennt. Til að byrja með var pað frekar tilviljunarkennt hvort aðstoðarmenn voru ráðnir. Á öðru tímabilinu var ráðning aðstoðarmanna regla frekar en hitt. Nýjasta tímabilið hófst árið 2011 með nýjum stjórnarráðslögum. Pau heimiluðu ráðherrum að ráða tvo aðstoðarmenn. Fyrir pann tíma hafði einungis verið heimilt að ráða einn aðstoðarmann með hverjum ráðherra (Gestur P. Reynisson og Ómar H. Kristmundsson 2014). Á mynd 4 má sjá próun aðstoðarmanna eftir áratugum. Segja má að peim hafi ekki fjölgað að ráði fyrr en slíkt var heimilað sérstaklega með stjórnarráðslögunum 2011. Lagabreytingunni hér á landi var ætlað að efla pólitíska stefnumótun en ekki sérstaklega samhæfingu. Meginhlutverk aðstoðarmanns ráðherra og ráðgjafa er pó að vinna að stefnumótun á málefnasviði ráðuneytis undir yfirstjórn ráðherra og í samvinnu við ráðuneytisstjóra. Engu að síður felur fjölgun aðstoðarmanna í sér tækifæri til að auka samhæfingu par sem pólitísk stefnumál krefjast oft aðkomu fleiri ráðuneyta. Đví parf oft að samræma sýn og nálgun pvert á ráđuneyti.

Fjölgun ráđgjafa í Svípjóð á áttunda áratugnum var ætlað að efla samhæfingu. Markmiðið var ekki pað sama hérlendis en pó leiddi fjölgunin til aukinna tækifæra til að efla pólitíska samhæfingu pvert á ráðuneyti. 


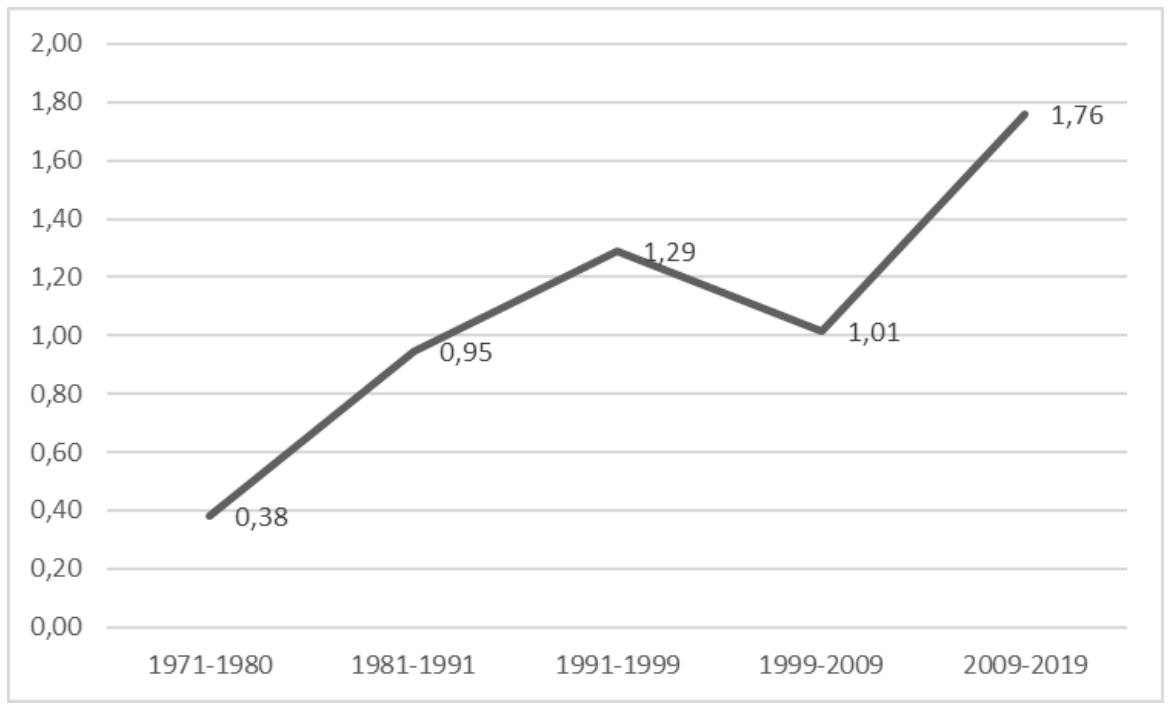

Mynd 4. Fjöldi ađstođarmanna ađ međaltali á hvern ráđherra í ríkisstjórn síđastliðna fimm áratugi

Heimild: Gögn birt í Gestur Reynisson og Ómar H. Kristmundsson (2014) auk upplýsinga um ráðuneyti Bjarna Benediktssonar og ráðuneyti Katrínar Jakobsdóttur.

Ein aðferð til að samhæfa störf innan stjórnkerfisins er með ráðherranefndum. Í flestum nágrannaríkjum er pað talin mikilvæg aðferð við að samhæfa störf ráðherra utan eiginlegra ríkisstjórnarfunda. Ráðherranefndir létta álagi af ríkisstjórn og gera umræður markvissari. Pær geta einnig gert forystumönnum í ríkisstjórnarsamstarfi auðveldara fyrir að sinna leiðsagnar- og eftirlitshlutverki sínu á einstökum málasviðum. Í Danmörku starfa að jafnaði um 20 ráðherranefndir. Má segja að par í landi séu störf slíkra nefnda ein helsta samhæfingaraðferð ríkisstjórna (Forsætisráðuneytið 2010a).

Lengi vel var aðeins ein ráðherranefnd, um ríkisfjármál, að störfum á Íslandi. prjár nefndir voru settar á fót til viðbótar við ríkisfjármálanefndina árið 2009. Fengust pær við jafnréttismál, Evrópumál og efnahagsmál og funduðu pær reglulega. Hjá núverandi ríkisstjórn eru fimm ráðherranefndir starfandi, um ríkisfjármál, um samræmingu mála, um jafnréttismál (sem jafnframt starfaði frá 2009-2013), um efnahagsmál sem nær jafnframt utan um endurskipulagningu fjármálakerfisins. Nýjasta ráðherranefndin var sett á laggirnar snemma árs 2019 og fjallar um matvælastefnu fyrir Ísland. Hlutverk ráðherranefndar um samræmingu mála er að samhæfa stefnu og aðgerðir í tilteknum málum par sem málefnasvið og ábyrgð ráðherra skarast. Eins og að tryggja vandaðan undirbúning mála og upplýsingaflæði á milli ráðherra. Nefndinni er auk pess ætlað að fylgja eftir innleiðingu verkefna í stjórnarsáttmála með markvissum hætti (Stjórnarráð Íslands e.d.).

\section{2 próun stjórnkerfismiðju yfir 15 ára tímabili}

Árið 2004 kom út samantekt um verkefni stjórnkerfismiðja sem náði til ríkja OECD, 
ríkja í Austur-Evrópu og ríkja á Balkanskaga. Samantektin var unnin af SIGMA, deild innan OECD og byggðist hún á spurningakönnun sem send var pátttökuríkjunum. Forsætisráðuneytið á Íslandi var á meðal pátttakenda í könnuninni á sínum tíma. Niðurstöðurnar gáfu til kynna að Ísland væri með frekar veika stjórnkerfismiðju samanborið við önnur OECD ríki. Detta átti sérstaklega við um formlegt samhæfingarhlutverk ráðuneytisins (OECD 2004). Greining SIGMA gaf aftur á móti góða mynd af pví hvernig staða stjórnkerfismiðjunnar væri í alpjóðlegum samanburði. Könnunin hefur ekki verið endurtekin undir sömu formerkjum. Árið 2018 var hins vegar sama könnunin gerð aftur á Íslandi, svörin gefa færi á að meta próunin hér landi síðastliðin 15 ár (Forsætisráðuneytið 2018). Sambærileg könnun hefur ekki verið gerð í öðrum ríkjum síðan 2003.

\section{Undirbúningur fyrir rikisstjórnarfund}

Árið 2003 voru engin tímamörk á pví hvenær ráðuneyti tilkynntu forsætisráðuneytinu um hvort taka ætti fyrir tiltekið mál á næsta fundi. Ísland var pá eina OECD ríkið sem tók pátt í könnuninni sem ekki var með skilgreindan fyrirvara. Árið 2018 var starfræktur rafrænn ríkisstjórnarbrunnur. Đegar um er að ræða einn fund í viku purfa gögn að berast premur dögum fyrir ríkisstjórnarfund í brunninn en pegar fundirnir eru tveir berast gögn einum degi fyrir fund (OECD 2004; Forsætisráðuneytið 2018).

Árið 2003 voru jafnframt engin tímamörk fyrir pví hvenær ráðuneyti ættu að upplýsa önnur ráðuneyti um málefni sem taka átti fyrir á næsta fundi. Öll önnur OECD ríki höfðu tiltekinn dagafjölda nema Svíar. Árið 2018 bar að upplýsa um mál einum til premur dögum fyrir fundi. Auk pess hafði samráð milli ráðuneyta á ráðuneytisstjórafundum stóraukist og nú eru öll áform um lagasetningu, p.e. áform um lagafrumvörp kynnt í ráðuneytisstjórahópi með góðum fyrirvara áður en vinna við gerð lagafrumvarps hefst (OECD 2004; Forsætisráðuneytið 2018).

\section{Virding fyrir reglunum}

Tímamörk vegna tilkynningarskyldu málefna voru oftast virt með undantekningum í OECD ríkjum árið 2003. Árið 2018 var tilkynningarskylda virt á Íslandi með mjög fáum undantekningum. Almennt báru ráðherrar í OECD ríkjunum, p. á m. Íslandi ekki upp mál nema pau væru á dagskrá ríkisstjórnarfunda árið 2003. Рað gerðist mjög sjaldan Íslandi árið 2018 og nánast aldrei án minnisblaða. Forsætisráðuneytið fær nánast alltaf upplýsingar um slík áform, p.e. ef ráðherrar óska eftir pví að taka upp tiltekin, oft viðkvæm mál, upp undir dagskrárliðnum „önnur mál““ (OECD 2004; Forsætisráðuneytið 2018).

\section{Frekari vinnsla á gögnum}

Svigrúm forsætisráðuneyta í OECD ríkjum til að endursenda gögn til ráðuneyta sem pörfnuðust frekari tæknilegrar útfærslu voru alla jafnan til staðar árið 2003. Баð var pó ekki raunin á Íslandi par sem forsætisráðuneytið hafði ekkert vald til að endursenda mál vegna tæknilegra vandkvæða (vantar gögn, skortur á samráði, vantar undirskrift o.s.frv). petta hefur breyst og hefur forsætisráðuneytið nú petta vald. Valdið felst vanalega í pví að viðkomandi ráðherra tekur pá málið aftur til baka og endurbætir pað, oftast í samráði 
við forsætisráðuneytið. Slík mál eru oft sett á biðmálaskrá ríkisstjórnar. Stundum eru pau pó tekin alfarið af dagskrá og koma ekki aftur á dagskrá fyrr en pau hafa verið endurbætt. Ennfremur fer forsætisráðuneytið yfir öll lagafrumvörp og pingsályktunartillögur ráðuneyta áður en pessi skjöl eru lögð fram í ríkisstjórn. Iðulega taka lagafrumvörpin töluverðum breytingum eftir ábendingar forsætisráðuneytisins (OECD 2004; Forsætisráðuneytið 2018).

Svigrúm forsætisráðuneyta til að endursenda var aðeins takmarkaðra pegar um stefnu eða áherslur í skjölunum var um að ræða. Á Íslandi hafði forsætisráðuneytið ekkert vald til að endursenda mál til ráðuneyta vegna stefnuáherslna í skjölunum. Árið 2018 hafði petta breyst að pví leyti að ráðuneytið gat endursent mál. Рað gerist pó mun sjaldnar á forsendum einhvers konar stefnumótunar. Ef pað gerðist er farvegurinn sá sami og ef um væri að ræða tæknileg vandkvæði (OECD 2004; Forsætisráðuneytið 2018).

\section{Mótun stefna og áctlana}

Geta forsætisráðuneyta til að starfa sem öflug stjórnkerfismiðja ræðst m.a. að pví hvort innan ráduneytisins starfi fólk með getu og hæfni til að móta stefnur og áætlanir fyrir ríkisstjórnir. Árið 2003 höfðu flestar skrifstofur forsætisráðuneyta OECD ríkja pessa getu. Á Íslandi var hún hins vegar ekki til staðar. Đað hafði pó breyst árið 2018 en pá var m.a. auknum fjármunum veitt til forsætisráðuneytisins til vinnu við stefnumótun. Sérstök skrifstofa stefnumála var stofnuð en stefnumótun er einnig sinnt af fleiri skrifstofum ráðuneytisins. Forsætisráðuneytið hafði árið 2003 getu og burði til að búa til ársáætlanir líkt og flest önnur OECD ríki og hafði enn árið 2018.

\section{Sambafingarfundir}

Samhæfingarfundir, par sem málefni voru rædd í ráðherranefndum áður en ákvörðun var tekin á ríkisstjórnarfundi, var skilyrði í mörgum OECD ríkjum árið 2003. Á Íslandi voru pað hins vegar einungis mikilvægustu málin sem rædd voru fyrir ríkisstjórnarfundi. Árið 2018 hafði petta breyst og eru nú ríkisfjármál og efnahagsmál rædd mjög reglulega og ýmis önnur mál sem krefjast samræmingar s.s. jafnréttismál, málefni flóttamanna, gjaldtaka fyrir nýtingu fiskveiðiauðlindarinnar, ferðamál, umhverfismál, samgöngumál o.fl. Đannig má segja að mál séu tekin oftar fyrir en pað er ekkert formlegt skipulag eða ákvæði um að slíkt skuli gera (OECD 2004; Forsætisráðuneytið 2018).

Árið 2003 voru ekki haldnir vikulegir fundir meðal embættismanna á Íslandi til að ræða og ákvarða mál á dagskrá ríkisstjórnarfunda. Đetta fyrirkomulag var til staðar í um helmingi peirra OECD ríkja sem tóku pátt í könnuninni 2003. Hér á landi hefur petta lítillega breyst. Samráð embættismanna og ráðherra fer fram fyrir hvern ríkisstjórnarfund par sem farið er yfir mál í ríkisstjórnarbrunninum, mál sampykkt eða ekki. Ef ekki er peim oftast frestað og málum raðað á endanlega dagskrá. Auk pess fer fram mikið samráð á fundum ráðuneytisstjóra, sem haldnir eru að jafnaði á tveggja vikna fresti. Par eru ýmis verkefni og áform kynnt og hefur pað aukist jafnt og pétt. Loks hafa aðrir ráðuneytisstjórar samband við ráðuneytisstjóra forsætisráðuneytisins og kanna hvort tiltekin mál geti komist á dagskrá (OECD 2004; Forsætisráðuneytið 2018). 


\section{Rádgöf}

Forsætisráðuneyti í ríkjum OECD veitir jafnan forsætisráðherra mikla ráðgjöf og árið 2003 undirbjuggu flest peirra minnisblöð fyrir forsætisráðherra um mál sem voru á dagskrá næstkomandi ríkisstjórnarfundar. Pessi minnisblöð innihéldu jafnan tillögur sem í flestum tilvikum voru aðeins unnar fyrir forsætisráðherrann en ekki aðra í ríkisstjórninni. Á pessum tíma veitti forsætisráðuneytið á Íslandi ekki svona ráðgjöf til handa forsætisráðherra. Árið 2018 voru svona minnisblöð einungis unnin í undantekningartilvikum, pegar um var að ræða mjög flókin mál. Öll gögn í ríkisstjórnarbrunni eru prentuð út fyrir forsætisráðherra og pegar pau liggja fyrir ákveður forsætisráðherra og sampykkir endanlega dagskrá. Баð kemur fyrir að pessi minnisblöð innihalda tillögur, einkum ef uppi hafa verið álitamál um málið á fyrri stigum. Ef minnisblöð sem pessi er unnið fyrir forsætisráðherra er pað einungis fyrir hann. Pví er hins vegar dreift til annarra ráðherra komi fram ósk pess efnis frá forsætisráðherra (OECD 2004; Forsætisráðuneytið 2018).

\section{Sambafing málefna}

Forsætisráðuneyti hafa aðkomu að ýmsum öðrum málum sem ekki teljast meginverkefni ráðuneytisins. Hlutverk peirra er mismikið pegar kemur að slíkum málum. Stundum eru pau leiðandi meðan annars staðar felst hlutverkið meira í að styðja önnur ráðuneytið við framkvæmd verkefna. Árið 2003 var spurt hvaða eining færi með samhæfingu vegna samskipta við Evrópusambandið. Meðal OECD ríkja var pað ýmist utanríkispjónustan ein og sér eða í samstarfi við forsætisráðuneyti. Á Íslandi hélt utanríkispjónustan um pessa samhæfingu árið 2003. Баð hafði breyst árið 2018 og nú stýrir forsætisráðuneytið svokölluðum stýrihópi Stjórnarráðsins um framkvæmd EES-samningsins. Ráðuneytisstjórar forsætisráđuneytisins og utanríkisráðuneytisins bera sameiginlega ábyrgð á framkvæmd samningsins (OECD 2004; Forsætisráðuneytið 2018).

раð er nokkuð breytilegt hvaða ráðuneyti fer með samhæfingu vegna umbóta í stjórnsýslunni (e. public administration reform) í OECD ríkjum. Árið 2003 var pað forsætisráðuneytið sem fór fyrir pessari samhæfingu innan Stjórnarráðsins. Árið 2018 var búið að skilgreina hlutverk forsætisráðuneytis pannig að pað færi með samhæfingu umbóta er varðar Stjórnarráðið (önnur ráđuneyti). Má par nefna í málum eins og próun upplýsingaréttar, aukið samráð sbr. samráðsgátt, siðareglur og endurmenntun starfsmanna Stjórnarráðsins með tilkomu Stjórnarráðsskólans árið 2010 o.s.frv. Hins vegar færi fjármála- og efnahagsráðuneytið með samhæfingu mála gagnvart ríkisstofnunum á sviði umbóta, innkaupa, eignarmála, nýsköpunar og opinberra fjármála (OECD 2004; Forsætisráðuneytið 2018).

\section{Fag og pólitiskar skrifstofur}

Í sumum ríkjum, sérstaklega peim stærri, er fjöldi pólitískt skipaðra ráðgjafa pað stór að hann kallast sérstök pólitísk skrifstofa ráðherra. Hún starfar sem einn angi af skipulagi forsætisráðuneytisins. Á Íslandi hafa verið pólitískir ráðgjafar í formi aðstoðarmanna en peir teljast ekki til sér skrifstofu innan forsætisráðuneytisins. Aðstoðarmenn ráðherra og ríkisstjórnarinnar heyra beint undir forsætisráðherra en ráðuneytisstjóri getur skipulagt 
störf peirra í samráði við ráðherra og gengið frá erindisbréfi fyrir hvern og einn (OECD 2004; Forsætisráðuneytið; 2018).

\section{Niðurstöður og ályktanir}

Ísland innleiddi nýskipan í ríkisrekstri frekar seint samanborið við helstu nágrannaríkin. Degar Ísland tók aftur á móti skrefið má segja að ekkert hálfkák hafi verið ástundað. Fjármálaráðuneytið einsetti sér á tíunda áratugnum að innleiða alla helstu meginpætti hugmyndafræðinnar. Rannsóknir hafa leitt í ljós að Ísland var með seinni skipunum að taka upp samhenta stjórnsýslu sem m.a. grundvallast á sterkri stjórnkerfismiðju. Bretar fóru fljótlega að huga að pessum málum eftir að Verkmannaflokkurinn undir forystu Tony Blair komst til valda árið 1997. Danir og Finnar vorum rúmum áratug á undan Íslendingum hið minnsta.

Eins og fram kom í inngangi var tilgangur pessar greinar prípættur, að kynna til leiks hugtak sem er lítt pekkt innan fræðinnar hér á landi. Fleiri pekkja hugtakið samhent stjórnsýsla (joined- up government) en segja má að stjórnkerfismiðjur sé eitt megin tækið til að ná fram samhentri stjórnsýslu. Í öðru lagi var ætlunin að setja petta hugtak í samhengi við pað sem er að gerast í öðrum ríkjum og reyna að skýra próunina út frá peim kenningum sem settar hafa verið fram. Í priðja lagi að greina, á grunni peirra gagna og upplýsinga sem til eru, hver próunin hefur verið hér á landi.

Almennt má segja að sameiginlegur skilningur sé meðal ríkja á pví hvað felist í hugtakinu, p.e. stjórnsýslueining sem pjóni framkvamdavaldinu, jmist forseta eða forsatisrádherra, auk ríkisstjornarinnar í heild. Á Íslandi er starfrækt stjórnkerfismiðja innan forsætisráðuneytisins 1 peim anda sem finna má 1 ýmsum öðrum OECD ríkjum. Hún er hins vegar ekki skilgreind sem slík í lögum, forsetaúrskurði eða á vefsíðu ráðuneytisins. Hlutverk stjórnkerfismiðja eru mjög svipað milli ríkja. Útfærslan er pó að vissu leyti mismunandi. Рað sama má segja um verkefnin. Ekki eru allar stjórnkerfismiðjur að gera hið sama og pær sem eru að gera sambærilega hluti kunna að hafa ólíkar nálganir. Dað ber pví að fara varlega í allan samanburð á stjórnkerfismiðjum milli ríkja par sem stjórnsýsluhefðir, menning, valdsvið forsætisráðherra og fleira hefur áhrif á pað hvernig stjórnkerfismiðjan starfar. Af peim leiðum sem ríki jafnan fara til að styrkja stjórnkerfismiðjur er fjölgun aðstoðarmanna líklega sú leið sem sjaldnast er farin. Hér á landi hefur verið meiri áhersla á samhæfingu pvert á ráđuneyti og eftirfylgni með forgangsmálum ríkisstjórna.

Eins og fram kom hjá Hood (1995) virðast tilefni og tækifæri skipta meira máli en aðrir pættir við að skýra af hverju ríki innleiða umbætur. Fjármálakrísan 2008 markaði án efa páttaskil í samfélaginu sem og í stjórnsýslunni hér á landi. Dað kallaði á gaumgæfilega endurskoðun á mörgum páttum, p. á m. endurskoðun á verkstjórnar- og samhæfingarhlutverki forsætisráðuneytisins.

Nú pegar rúmur áratugur er liðinn frá pví að forsætisráðuneytið fékk aukið forystuog samhæfingarhlutverk innan Stjórnarráðsins er rétt að meta hvernig stjórnkerfismiðjan hefur próast. Á Íslandi fjölgaði aðstoðarmönnum í kjölfar breytinga á stjórnarráðslögunum 2011 og gefur fjölgunin til kynna að hægt sé að efla ýmsa pætti samhæfingar og eftirfylgni. Niðurstöður könnunarinnar frá árinu 2018 gefa til kynna að stjórnkerfismiðjan í 
forsætisráðuneytinu hefur tekið miklum breytingum á síðastliðnum árum. Segja má að hún standi nær nágrannaríkjunum í dag en hún gerði fyrir 15 árum síðan hvað verkefni og skipulag varðar. Má hér nefna fjölgun ráðherranefnda og markvissari eftirfylgni með stjórnarsáttmála. Einnig hefur lagaskrifstofa ráđuneytisins skilgreint og ferlavætt hlutverk sitt til að tryggja vandaðri frumvarpagerð ráðuneyta. Skrifstofa yfirstjórnar heldur utan um samráð á æosta stigi, ríkisstjórnarfundi og ráðherranefndarfundi. Skrifstofa stefnumála heldur hins vegar utan um aðgerðalista stjórnvalda, ýmist með virkri pátttöku eða markvissri eftirfylgni. Í skýrslunni Samhent stjórnsýsla (2010a) var lagt til að miðlægt hlutverk forsætisráðuneytisins og fjármálaráðuneytisins yrou skýrð sérstaklega. Einnig skyldi tryggja gott samstarf peirra í millum svo gott samhengi yrði milli stefnu ríkisstjórnar og tillagna fyrir Alpingi um útdeilingu fjármuna. Í ljósi peirra breytinga sem orðið hafa á fjárlagagerðinni með tilkomu laga um opinber fjármál hefur stefnumótun orðið virkur páttur í vinnu ráðuneyta við gerð fjárlaga. Breytingin gerir forsætisráðuneytinu betur kleift en áður að tryggja framkvæmd og eftirfylgni með verkefnum sem sett eru fram í stjórnarsáttmála pó pað hafi ef til vill ekki verið tilgangurinn með gerð laganna.

Stjórnkerfismiðja parf skýran lagagrundvöll og öflugt skipulag sem nær yfir hlutverk og verkefni einingarinnar. Finna má fyrirmyndir á Norðurlöndunum og í Bretlandi sem læra má af. Hafa ber í huga að allar stjórnkerfismiðjur lenda í átökum við önnur ráðuneyti eða aðra aðila innan kerfisins. Kann pað að vera vegna skilningsleysis á stöðu og hlutverki einingarinnar eða vegna takmarkaðs áhuga á afskiptum hennar af málum sem heyra formlega ekki undir hana. ๖að er pví stöðug vinna fyrir stjórnkerfismiðju að framfylgja hlutverki sínu.

\section{Heimildaskrá}

Alessandro, M., Lafuente, M. og Santiso, C. (2013). The role of the center of government: A literature review (Technical Note IDB-TN-581). Washington, DC: Inter-American Development Bank.

Barber, M. (2008). Instruction to Deliver: Fighting to Transform Britain's Public Services. London: Methuen Publishing.

Barber, M. (2016). How to run a government: So that citizens benefit and taxpayers don't go Crazy. UK: Penguin.

Bonvecchi, A. og C. Scartascini. (2011). The Presidency and the Executive Branch in Latin America: What We Know and What We Need to Know (IDB Working Paper Series IDB-WP-283). Washington, DC: InterAmerican Development Bank.

Chakrabarti, S. (2007). Role of the Cabinet Office - Leadership through Effective Collaboration. London: Cabinet Office.

Christensen, T. og Lægreid, P. (2007). „The Whole-of-Government Approach to Public Sector Reform", Public Administration Review 67(6), 1059-1064.

Christensen, T. og Lægreid, P. (2019). „Coordination Quality in Central Government - the Case of Norway“, Public Organization Review, 1-18.

Clarke, M. og Stewart, J. (1997). Handling the Wicked Issues: A Challenge for Government (INLOGOV Discussion Paper). Birmingham: University of Birmingham.

Dahlström, C., Peters, G. og Pierre, J. (2011). Steering from the Centre. Strengthening Political Control in Western Democracies. Toronto: University of Toronto Press.

Dumas, V., Lafuente, M. og Parrado, S. (2013). Chile: Fortaleciendo el Centro de Gobierno para Resultados. La experiencia del Ministerio Secretaria General de la Presidencia y su Unidad Presidencial de Gestión del Cumplimiento (2010-2013) (Technical Note IDBTN-563). Washington, DC: Inter-American Development Bank. 
Egaña, R. og Chateau, J. (2011). „El Centro de Gobierno: Lecciones de la Experiencia Chilena durante los Gobiernos de la Concertación (1990-2010)", Revista Chilena de la administración Pública 17, 137-191.

European Commission (2017). Quality of public administration A toolbox for practitioners: Abridged version. Luxembourgh: Publication office of the European Union.

Evans, G. (2013). Interview with Michael Scharff, Innovations for Successful Societies (Series on Centers of Government). Princeton, NJ: Princeton University.

Forsætisráðuneytið (2010a). Sambent stjórnsýsla. Sótt af https://www.stjornarradid.is/lisalib/getfile. aspx?itemid $=01119619-412 \mathrm{c}-11 \mathrm{e} 7-9410-005056 \mathrm{bc} 4 \mathrm{~d} 74$

Forsætisráðuneytið (2010b). Viðbrögð stjórnsýslunnar við skýrslu rannsóknarnefndar Alpingis. Sótt af https:// www.stjornarradid.is/media/forsaetisraduneyti-media/media/skyrslur/skyrsla-starfshops-6mai2010.pdf

Forsætisráðuneytið (2018). „Svör ráðuneytisstjóra við spurningakönnun“, óbirt skrifleg könnun maî 2018.

Gaetani, F. (2011). „La dinámica de la coordinación en el ámbito del ejecutivo. Una reflexión a partir delas variaciones y contrastes en los dieciséis años de Cardoso y Lula“, í N.C Grau, J.C.F. Toro og M.A. Sáez (ritsti), Fortalecimiento del Alto Gobierno. Aproximaciones Conceptuales (bls. 425-453). Caracas: CLAD

Gestur P. Reynisson og Ómar H. Kristmundsson (2014). „Hverjir verða aðstoðarmenn?“, Stjórnmál \& stjórnsýsla 10(2), 167-188.

Gunnar Helgi Kristinsson, Halldór Jónsson og Hulda Póra Sveinsdóttir (1992). Atvinnustefna á Íslandi 1959-1991. Reykjavík: Félagsvísindastofnun Háskóla Íslands.

Gunnar Helgi Kristinsson (1999). Úr digrum sjóơi. Reykjavík: Háskólaútgáfan.

Gunnar Helgi Kristinsson (2007). „Lýðræðisleg ábyrgð og rekstrarform“, Stjórnmál \& stjórnsýsla 3(2), 223-234.

Gunnar Helgi Kristinsson og Pétur Berg Matthíasson (2014). „Stjórnsýsluumbætur og árangur og peirra“, Stjórnmál \& stjórnsýsla 10(2), 307-326.

Haddad, C., Klouche, M. og Heneine, Y. (2010). Center of Government. The Engine of Modern Public Institutions. New York, NY: Booz \& Company.

Hood, C. (1991). „A Public Management for all seasons?", Public Administration 69, 3-19.

Hood, C. (1995). „The "New Public Management” In the 1980s: Variations on a theme“, Accounting Organizations and Society 20, 93-109.

Institute for Government (2013). The Engine Room: How to Organize 10 Downing Street. London.

James, S. og Ben-Gera, M. (2004). A Comparative Analysis of Government Offices in OECD Countries (Public Governance Committee). Paris: Organisation for Economic Cooperation and Development.

Lög um Stjórnarrád Íslands nr. 115/2011.

Ministry of Finance (2013). Governments for the Future Main Report November 2013. Finland.

OECD (2004). „Co-ordination at the Centre of Government: The Functions and Organisation of the Government Office Comparative; Analysis of OECD Countries, CEECs and Western Balkan Countries“, SIGMA Papers 35. Paris: OECD Publishing. http://dx.doi.org/10.1787/5kml60v4x2f6-en

OECD (2005). Public Sector Modernisation: The Way Forward. Paris. OECD.

OECD (2007). „The Role of Ministries in the Policy System: Policy Development, Monitoring and Evaluation", Sigma Papers 39. Paris: OECD.

OECD (2008). Public Governance Reviens, Ireland: Towards An Integrated Public Service. Paris: OECD.

OECD (2010a). Public Governance Reviens, Finland: Working Together to Sustain Success. Paris: OECD.

OECD (2010b). Public Governance Review, Estonia: Towards a Single Government Approach, Assessment Document. Paris: OECD.

OECD (2018). Centre Stage, OECD Centres of Government, Paris: OECD.

Ómar H. Kristmundsson (2003). Reinventing Government in Iceland. Reykjavik: University of Iceland Press.

Pollitt, C. og Bouckaert, G. (2011). Public management reform: a comparative analysis (3. útg.). Oxford: Oxford University Press.

Pollitt, C. og Dan, S. (2013). „Searching for impacts in performance-oriented management reforms: 


\section{STJÓRNSÝSLA}

review of the European literature“, Public Performance and Management Review, 1-34. Sótt af http:// hdl.handle.net/1765/40909

Prats I Catalá, J., og Villoria, M. (2011). „El apoyo al Alto Gobierno: la coordinación y coherencia gubernamental“" í Fortalecimiento del Alto Gobierno. Aproximaciones Conceptuales. Caracas: Centro Latinoamericano para la Administración y el Desarrollo.

Relyea, H. (2008). The Executive Office of the President: an Historical Overview. Washington, DC: Congressional Research Service.

Richards, D. og Smith, M. (2006). „Central control and policy implementation in the UK: a case study of the Prime Minister's Delivery Unit", Journal of Comparative Policy Analysis: Research and Practice 8(4), 325-345.

Sartori, G. (1994). Ingeniería Constitucional Comparada. Una investigación de estructuras, incentivos y resultados. Mexico, DF: Fondo de Cultura Económica.

Stjórnarrád Íslands (e.d). Rádherranefndir. Sótt af https://www.stjornarradid.is/rikisstjorn/radherranefndir/

Wanna, J. (2006). „From Afterthought to Afterburner: Australia's Cabinet Implementation Unit“, Journal of Comparative Policy Analysis: Research and Practice 8(4), 347-369.

World Bank (2010). The Practice of Policy-Making in the OECD: Ideas for Latin America. Public Sector and Governance Unit, Latin America and the Caribbean Region. Washington, DC: World Bank. 
